\title{
Congenital hereditary corneal oedema of Maumenee: its clinical features, management, and pathology
}

\author{
COLIN M KIRKNESS,' ALISON MCCARTNEY, ${ }^{2}$ NOEL S C RICE,' \\ ALEC GARNER, ${ }^{2}$ AND ARTHUR D McG STEELE ${ }^{1}$ \\ From the ${ }^{1}$ Corneal Clinic, Moorfields Eye Hospital, London, and the ${ }^{2}$ Department of Pathology, Institute of \\ Ophthalmology, London
}

SUMMARY The clinical and histological features of congenital hereditary corneal oedema in 23 patients are presented. The series includes cases of both recessive and dominant inheritance. Although the condition is present at birth or in early childhood, visual development appears to be little impaired, if at all. Penetrating keratoplasty carries a relatively good surgical prognosis and can produce a substantial visual gain even when carried out late in life.

Congenital corneal opacities have been recognised since last century. Several underlying abnormalities have been described, including sclerocornea, Peters' anomaly, and congenital corneal clouding. This latter, congenital hereditary corneal dystrophy, had been described in the European ophthalmic literature ${ }^{1-7}$ but it was not until Maumenee' ${ }^{8}$ report that the primary pathology was recognised as an anomalous development of the corneal endothelium. Since that time a number of further reports have appeared, mostly as individual cases ${ }^{2-13}$ but also in the form of small series. ${ }^{1418}$ It is clear that there has been duplication of material between several of these publications. Recent reports have concentrated on description of the ultrastructural abnormalities in this condition. Judisch and Maumenee ${ }^{18}$ made an attempt to differentiate the clinical behaviour of the oedematous corneas on the basis of dominant or recessive inheritance, but without regard for the ultrastructural details in either case.

The prognosis for useful vision in patients with congenital hereditary corneal oedema is still said to be poor, and penetrating keratoplasty is likewise thought to carry a poor prognosis of graft survival. ${ }^{19}$

In an effort to document the clinical manifestations of this condition and to elucidate useful prognostic factors as to maintenance of visual function and likely outcome of penetrating keratoplasty we report a series of 23 patients presenting to the surgeons of the

Correspondence to Colin M Kirkness, FRCS, Department of Clinical Ophthalmology, Institute of Ophthalmology, Moorfields Eye Hospital, City Road, London EC1V 2PD.
Corneal Clinic at Moorfields Eye Hospital during the period 1971-86.

\section{Materials and methods}

Cases of congenital endothelial dystrophy were identified retrospectively from the cases notes of patients attending the Corneal Clinic, Moorfields Eye Hospital. All patients have been under the care

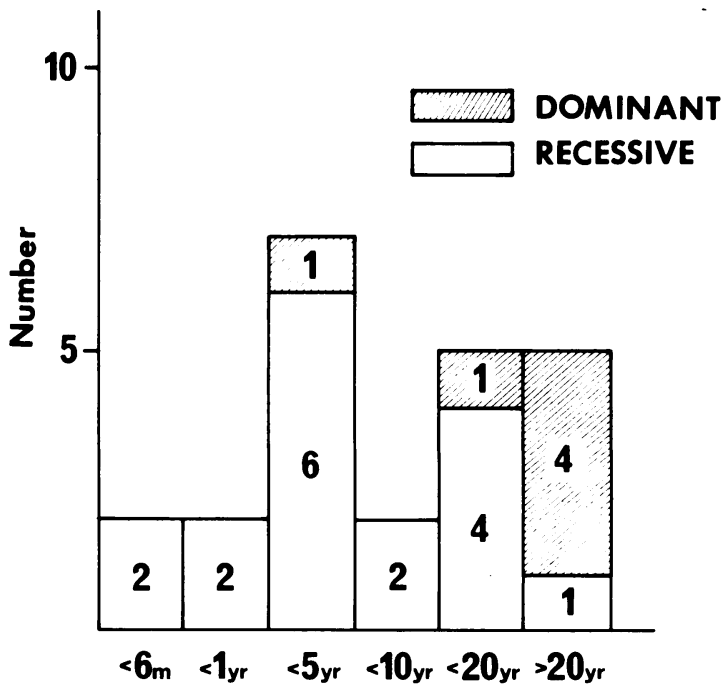

Fig. 1 Age at presentation. The cross-hatched portions of the histograms in Figs. 1, 2, and 7 represent those patients with the dominant inheritance pattern. 


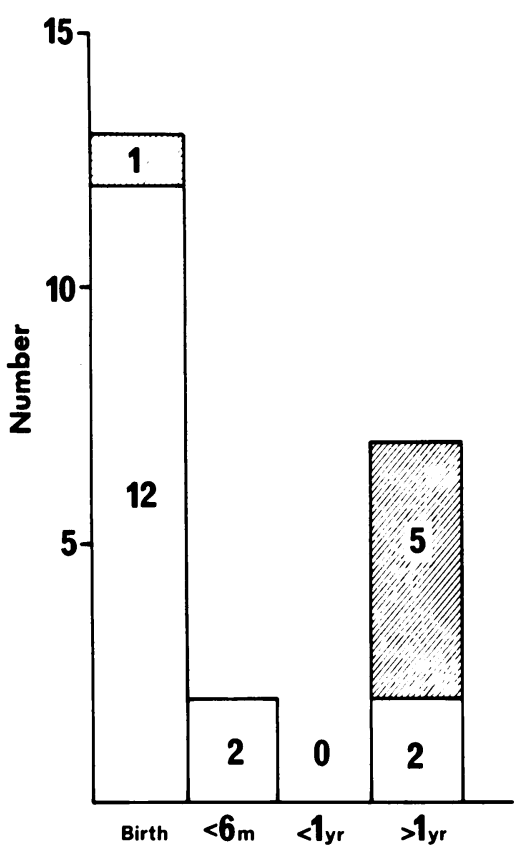

Fig. 2 Age at onset of symptoms or signs. In one case it was not known when in childhood the signs first appeared.

of at least one of the authors personally. The diagnosis of congenital hereditary corneal oedema was made on the basis of clinically recognisable, bilateral, corneal oedema developing in early life, and in the absence of any other anterior segment abnormality. Twenty-three affected individuals were identified, presenting between the ages of 3 months and 61 years, mean 13.5 years (Fig. 1). Corneal clouding had been observed in these patients from birth to as late as 8 years (Fig. 2). There were 15 males and 8 females.

One family was observed whose inheritance pattern was clearly autosomal dominant, and here the sex distribution of those seen was one male to five females, and 6:19 overall (Fig. 3, Figs. 4A, B, C). The remaining patients had either an autosomal recessive pattern (eight patients) or probable recessive pattern (nine patients). Fifteen patients were British, five Iranian, three Saudi Arabian, and one was Pakistani (Figs. 5A, B).

Progression of the corneal signs-that is, increase in oedema, development of corneal stromal scarring, and deposition of opaque plaques-was observed in four of the recessives and three of the dominants (Fig. 6). Vascularisation was clinically apparent in two patients over 50 years of age. Spheroidal keratopathy was seen in three of the dominants who were over 30 years of age and a similar change was seen in one 24-year-old recessive from Iran. One recessive case showed a temporary regression of the signs but at no time did he achieve normal visual acuities. No patient had any other anterior segment, developmental abnormality.

Five patients had undergone glaucoma surgery elsewhere, one in adulthood, the others in infancy (Table 1). In three patients, including one dominant, there was manifest nystagmus, and one had latent nystagmus. Strabismus was seen in four patients; one had an esotropia, two had an exotropia, and one an exophoria. No patient had both a squint and nystagmus.

One further case, a child aged 7 years, developed an exodeviation following his first graft, but this recovered after the second eye received a graft with evidence of good retained binocular function. No patient had any associated systemic abnormality.

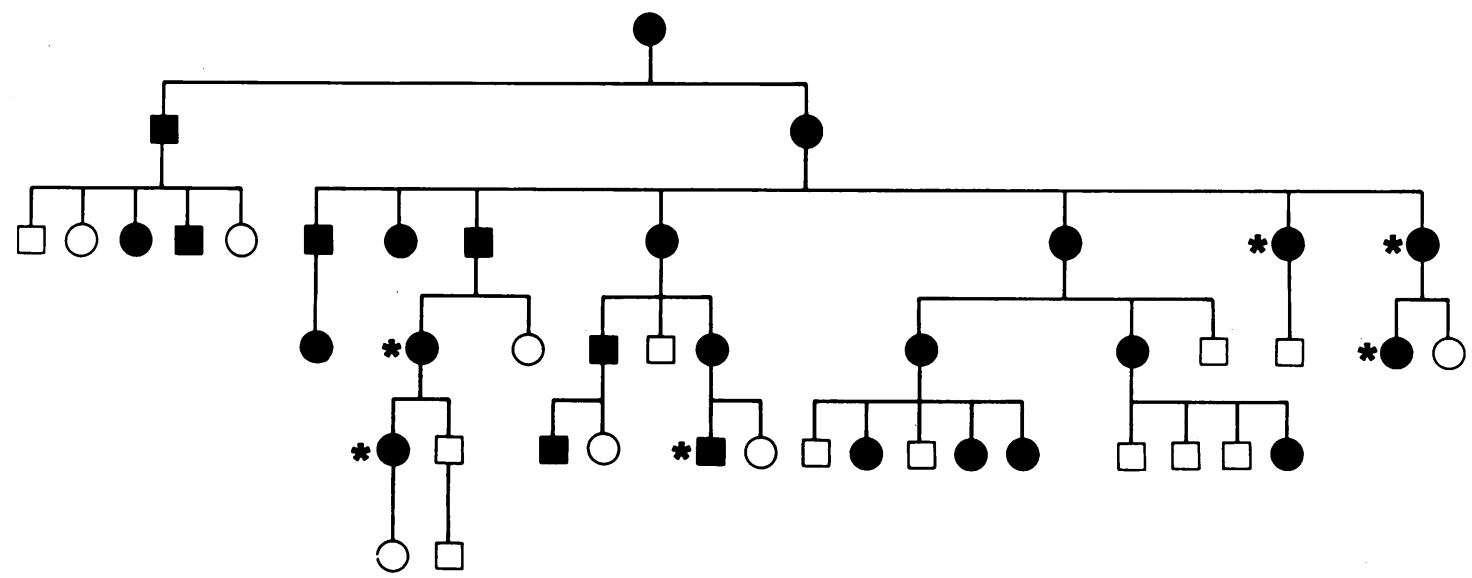

Fig. 3 Dominantly inherited congenital corneal oedema. The solid symbols represent those affected. Those marked with * are under the care of Moorfields Corneal Clinic. 
Fig. 4 An 11-year-old male with dominantly inherited corneal oedema. This patient had shown signs of progression and at the age of two had had a superficial calcified plaque excised. A: The cornea shows diffuse, variable oedema involving the stroma and epithelium. B: Slit photograph of the same eye. The acuity is 6/60. C: The same eye two months postoperatively. The acuity is $6 / 36$.

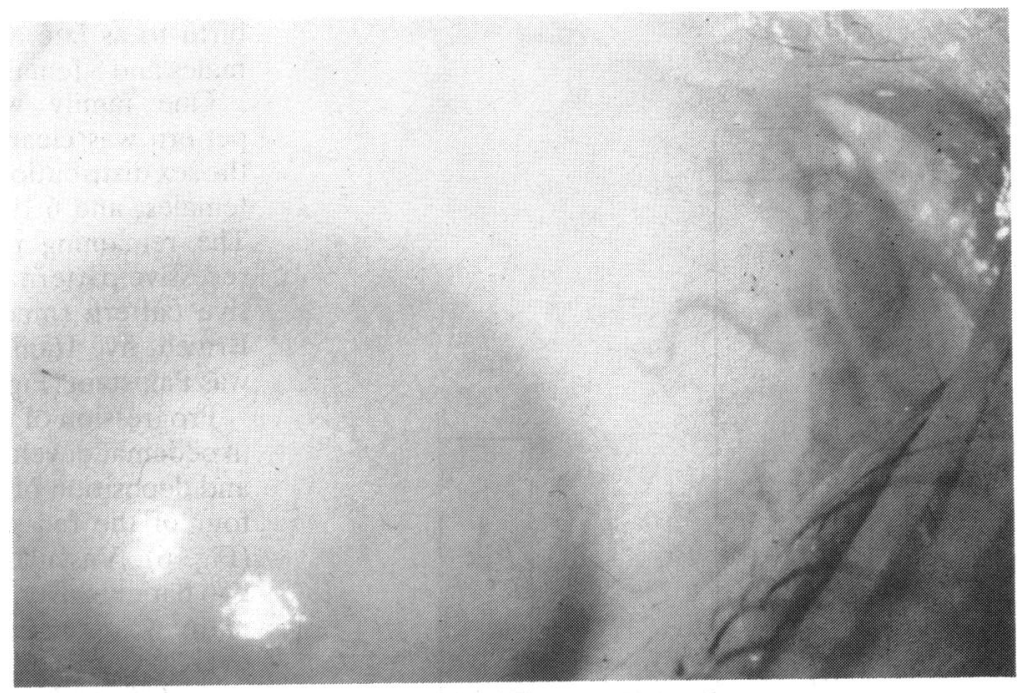

Fig. 4A

\section{Results}

\section{SURGERY}

Twenty patients underwent penetrating keratoplasty, nine unilaterally and 11 bilaterally, that is, 31 eyes had penetrating grafts. A total of 37 grafts were performed on these eyes. This included one eye which had a combined trabeculectomy and penetrating keratoplasty, having had a previous trabecu-

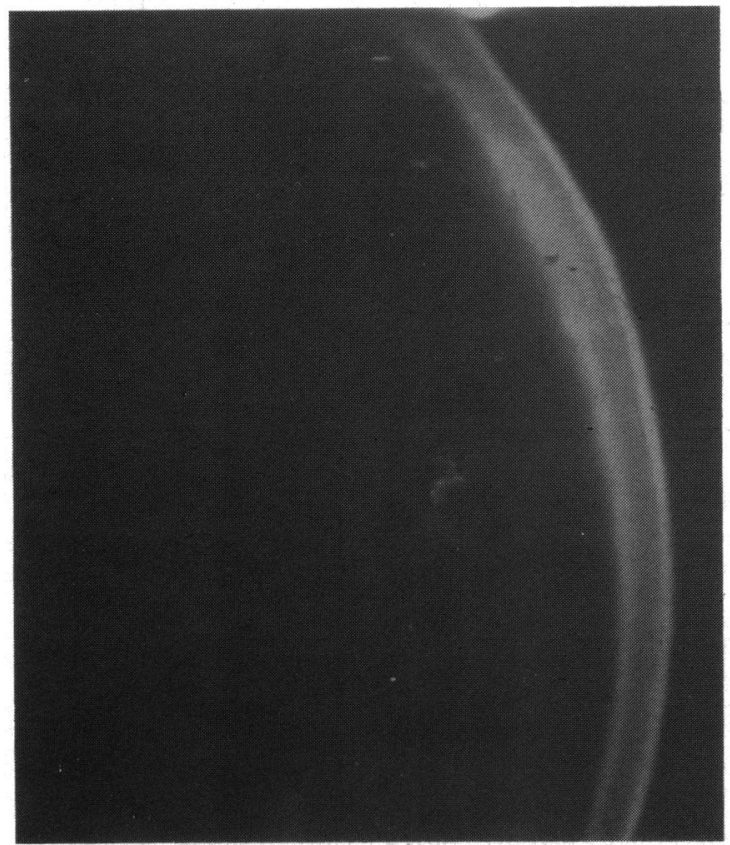

Fig. 4B lectomy. Follow-up was from six weeks to 11 years (mean 39 months).

Three patients did not undergo keratoplasty (Table 2). The age at which the first graft was performed in any individual is shown in Fig. 7. The size of the grafts varied from $6 \mathrm{~mm}$ to $8 \mathrm{~mm}$ (Fig. 8).

In those eyes receiving a graft the preoperative visual acuity was less than $6 / 60$ except in three eyes, whose acuity was $6 / 24,6 / 36$, and $6 / 60$ respectively.

The results of penetrating keratoplasty are summarised in Figs. 9-11. Penetrating keratoplasty resulted in a significant improvement of visual acuity in every eye while the graft remained clear. By six months after keratoplasty the majority of eyes $(66 \%)$ attained a best corrected acuity of $6 / 18$ or better, which is equivalent to an improvement of at least three lines on the Snellen chart. The acuity achieved

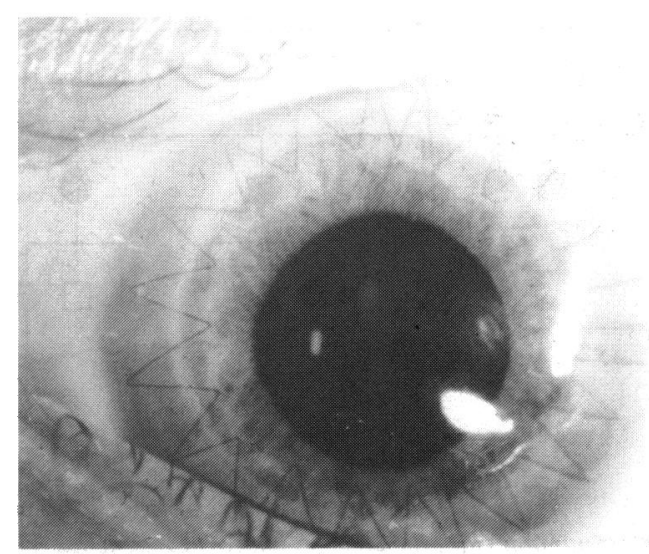

Fig. 4C 


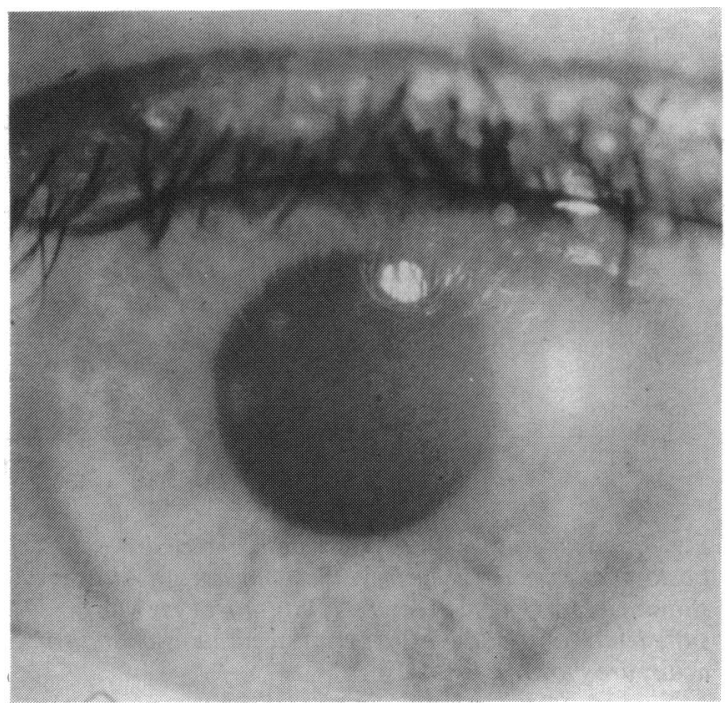

Fig. 5A

Fig. 5 A 14-year-old male with a recessive inheritance pattern. A: The cornea shows diffuse stromal oedema which appears relatively mild. The acuity is $<6 / 60$. B: The same eye two months postoperatively. The acuity is $6 / 18$.

after successful keratoplasty did not correlate with the age at which the ocular abnormality was first observed or the age at which surgery was undertaken, though it is interesting to note that the three patients whose gain was least were also the oldest three patients at the time of surgery.

\section{COMPLICATIONS}

One patient showed a transient rise in intraocular pressure which reverted to normal following

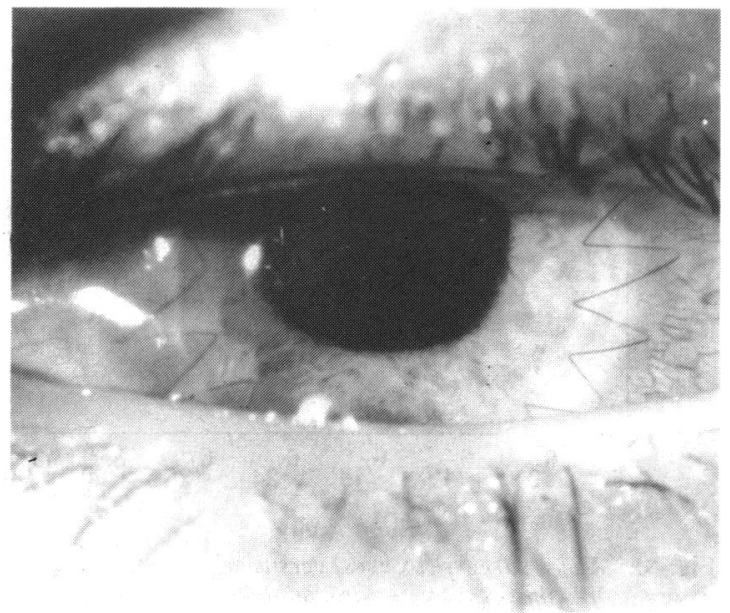

Fig. 5B

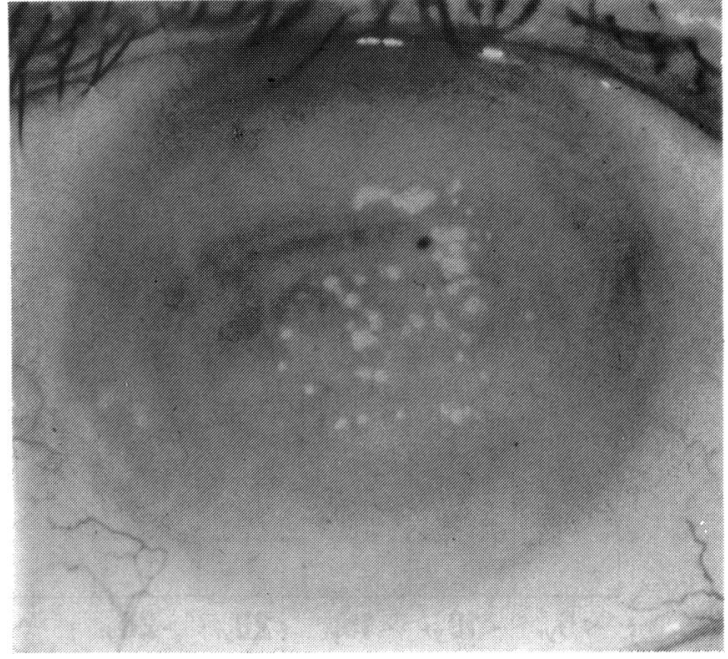

Fig. 6 A30-year-old female with a dominant inheritance pattern. The cornea is grossly thickened and the epithelium irregular. There is spheroidal degenerative change in the anterior stroma but little sign of vascularisation. This patient saw 6/12 postoperatively.

cessation of topical steroid therapy. Corneal graft rejection episodes were encountered in four eyes. In only one eye was this successfully reversed and the graft clarity preserved (Table 3 ). Of the other three eyes two were successfully regrafted and currently retain clear grafts. The remaining eye was regrafted on three further occasions, but all grafts were rejected. The rejection episodes were seen only in patients operated upon before 15 years of age.

One graft developed suppurative keratitis and became opaque. One eye suffered a traumatic rupture of the graft-host wound eight months following keratoplasty, with loss of lens, iris, and vitreous

Table 1 Summary of those patients who had had previous glaucoma surgery

\begin{tabular}{lll}
\hline Age & Sex & Procedure \\
\hline 21 & F & Trabeculectomy \\
$<1$ & F & Bilateral goniotomy \\
$<1$ & M & Bilateral goniotomy and bilateral iris inclusion \\
$<1$ & F & Bilateral trabeculectomy twice \\
$<1$ & F & Bilateral drainage five times \\
\hline
\end{tabular}

Table 2 Patients not undergoing surgery

\begin{tabular}{lllll}
\hline Sex & $V A R$ & $V A L$ & Age & Otherfeatures \\
\hline M & $6 / 60$ & $6 / 36$ & 13 & Had goniotomy \\
M & $6 / 36$ & CF & 20 & - \\
M & $6 / 24$ & $6 / 24$ & 13 & Manifest divergent squint \\
\hline
\end{tabular}

$\mathrm{VA}=$ visual acuity $. \mathrm{CF}=$ counting fingers . 


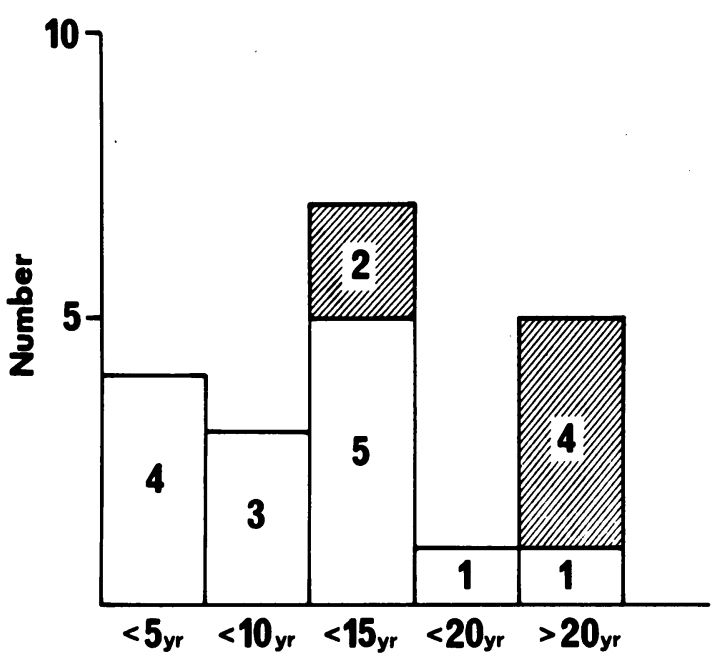

Fig. 7 Age of patient when first graft performed.

gel, and subsequent decompensation of the graft endothelium. This eye showed no evidence of a rejection episode.

There were thus only three failures out of 31 eyes $(10 \%)$ to maintain a clear graft and useful vision.

\section{HISTOLOGY}

Light microscopic (LM) sections from 26 corneas were reviewed. These included three patients not part of the clinical series of which two were previously reported on by Pearce et al. ${ }^{14}$ Most of the

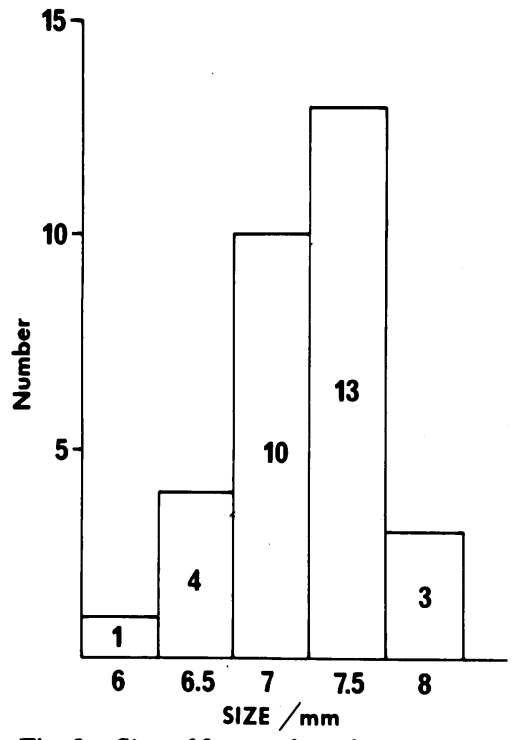

Fig. 8 Size of first graft performed (by eyes).

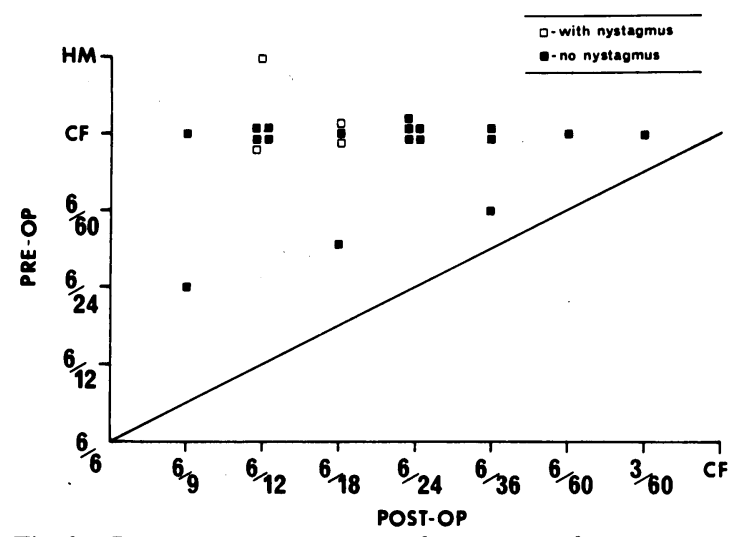

Fig. 9 Preoperative acuity versus best corrected postoperative acuity in each eye receiving a graft. All eyes showed improvement in acuity. (Only those eyes with sufficiently long follow-up to permit accurate estimation of acuity are shown.)

specimens were of full thickness corneal discs. In some of the earlier cases only lamellar specimens were received, and Descemet's membrane and endothelium were not available for comment. Twenty cases, including nine from three generations of the autosomal dominant family, were examined. Electron microscopy (EM) of the cornea was performed on four members of this family (the two more senior members were previously reported on $^{14}$ in 1969). The EM results in the dominant group were compared with those of six corneas from five patients with the recessive form of the condition.

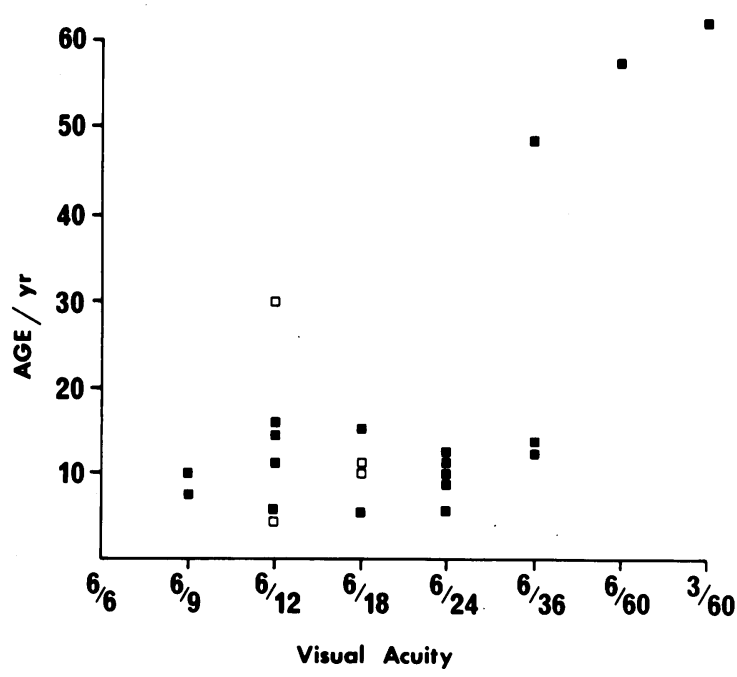

Fig. 10 Age at surgery (by eyes) versus best corrected acuity. (Only those eyes with sufficiently long follow-up to permit accurate estimation of acuity are shown.) 


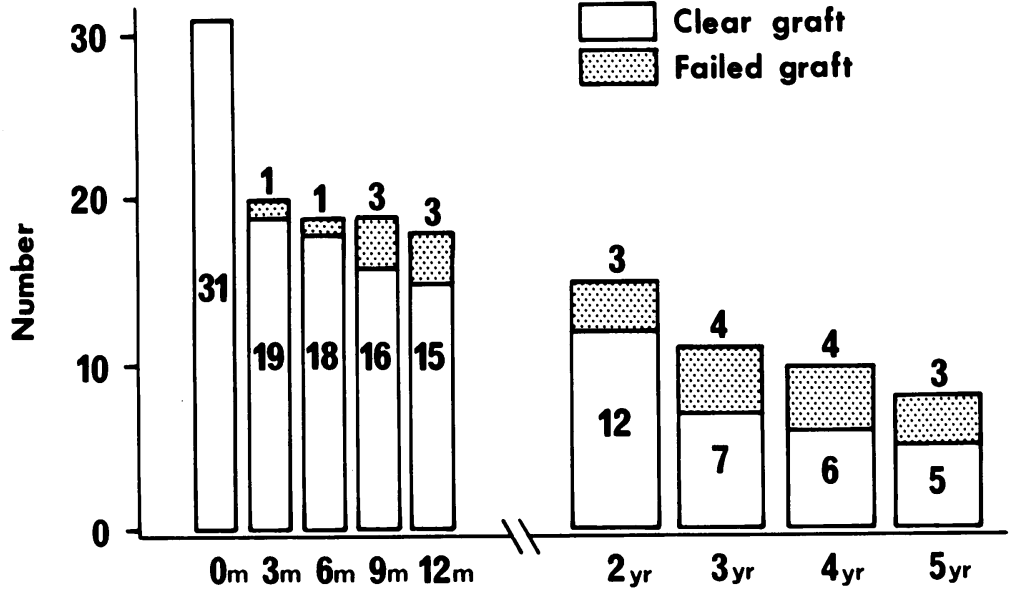

Fig. 11 Graft survival against follow up. The numbers shown refer to the first graft in any eye. The survival of regrafts is not shown. Note the discontinuity of the time axis.

\section{Light microscopy}

Changes were observed in all corneal tissues, and the results are summarised in Table 4. Marked atrophy of the epithelium was observed in five corneas from the dominantly inherited group and three from the recessives. Most epithelia showed basal oedema (Figs. 12, 13). Subepithelial fibrosis was more marked in the dominant group, seen in $60 \%$ of the biopsies but only in three of 16 from the recessive patients. Calcification of the subepithelial zone was present only in two of the dominant patients and none of the recessives (more was seen in the deep stroma at EM level).

Partial loss of Bowman's membrane was extremely common, seen to some extent in all of the dominant patients and all but two of the recessives. Stromal changes, at light level, were objectively confined to reporting the presence or absence of spheroidal (droplet) degeneration, present in six of the

Table 3 Graft failures

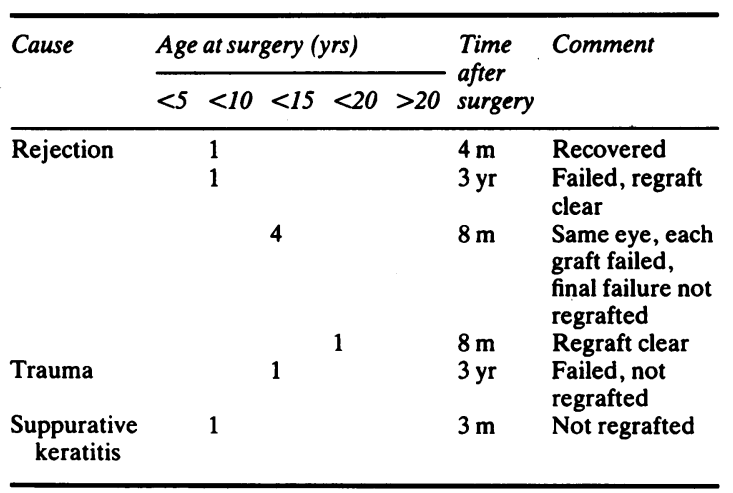

Seven rejected grafts in four eyes, out of a total of 26 eyes grafted. Only three eyes had opaque grafts. dominant group's biopsies but only in one recessive. Neovascularisation of the stroma was seen by LM in only two dominant patients; both of these patients had long standing disease presenting late for surgery.

The thickness of Descemet's membrane (DM) was measured in the majority of cases (at $\times 400)$ with an eyepiece graticule. Whenever possible the results were confirmed by EM. In the dominant group four DMs were in the range of 6-10 $\mu \mathrm{m}$ (Fig. 14), while three were much thicker-up to $21 \mu \mathrm{m}$ in depth. None of the dominant group showed the more uniform thickening observed in some of the recessive patients, where measurements of 22-24 $\mu \mathrm{m}$ were seen. Only one DM in a 3-year-old child was of normal thickness. None of the recessives showed thinning or loss of definition of DM. Lamination, particularly under periodic-acid-Schiff staining, was not especially common. Retrocorneal fibrosis with a prominent posterior collagenous layer was seen in four cases, only one of which was recessive.

Endothelium was discernible in most of our cases, but loss of cells and degeneration were common. The changes ranged from atrophy with vacuolation to focal absence of cells. In some areas normal cells were seen. Multilayering of endothelial cells was demonstrable in only one case at light microscopic level. Melanin was seen in 14 of the 26 corneas, in attenuated endothelial covering cells.

\section{Electron microscopy}

Electron microscopy was used to characterise the apparently primary changes at the level of DM and the endothelium. Amorphous deposits of electron dense material were seen at the sites of spheroidal degeneration in two of the four dominant cases but in none of the five recessives examined. In two dominant cases the stroma had previously been reported as showing separation of lamellae, fragmen- 
Table 4 Light microscopic changes

\begin{tabular}{|c|c|c|c|c|c|c|c|c|c|c|c|c|c|c|}
\hline \multirow[t]{2}{*}{ Case } & \multirow[t]{2}{*}{ Age } & \multirow{2}{*}{$\begin{array}{l}\text { Previous } \\
\text { surgery }\end{array}$} & \multicolumn{2}{|c|}{ Epithelium } & \multirow{2}{*}{\multicolumn{2}{|c|}{$\begin{array}{l}\text { Subepithelial } \\
\text { fibrosis/calcification }\end{array}$}} & \multirow{2}{*}{$\begin{array}{l}\text { Bowman's } \\
\text { zone } \\
\text { deficiency }\end{array}$} & \multicolumn{2}{|l|}{ Stroma } & \multicolumn{2}{|l|}{$\begin{array}{l}\text { Descemet's } \\
\text { membrane }\end{array}$} & \multicolumn{3}{|c|}{ Endothelium } \\
\hline & & & Atrophy & $\begin{array}{l}\text { Basal } \\
\text { oedema }\end{array}$ & & & & Vessels & $\begin{array}{l}\text { Spheroidal } \\
\text { degenera- } \\
\text { tion }\end{array}$ & $\begin{array}{l}\text { Max width } \\
\mu m\end{array}$ & $\begin{array}{l}\text { Lamina- } \\
\text { tion }\end{array}$ & Deficiency & Multilayer & Melanin \\
\hline \multicolumn{15}{|c|}{ Dominant } \\
\hline $1 \mathrm{a}$ & 62 & - & + & + & + & - & ++ & + & + & 6-7 & - & ++ & - & + \\
\hline $1 b$ & 65 & - & + & - & + & $+1-$ & ++ & $+1-$ & +++ & $19-21$ & + & ++ & - & + \\
\hline 2 & 57 & - & + & - & + & - & ++ & - & + & $19-21$ & + & ++ & - & - \\
\hline 3 & 58 & - & ++ & + & + & - & ++ & - & + & $\mathrm{n} / \mathrm{a}$ & + & ++ & - & - \\
\hline 4 & 20 & - & - & $+1-$ & + & - & ++ & - & - & 14 & - & $+1-$ & - & - \\
\hline $5 \mathrm{a}^{*}$ & 4 & - & - & - & + & + & ++ & - & + & & & & & \\
\hline $5 b$ & 14 & - & $+1-$ & - & - & - & ++ & - & - & 7 & & $+1-$ & - & - \\
\hline 6 & 31 & + & $+1-$ & + & - & - & $+1-$ & + & + & $6-7$ & & + & - & + \\
\hline $7^{*}$ & 37 & - & ++ & - & - & - & + & - & - & $6-10$ & & ++ & - & + \\
\hline 8 & 6 & - & + & - & - & - & + & - & - & $\mathbf{n} / \mathbf{a}$ & & & & \\
\hline \multicolumn{15}{|c|}{ Recessive } \\
\hline 10 & 7 & - & - & - & - & - & $+1-$ & - & - & $9-10$ & & - & - & - \\
\hline 11 & 24 & - & + & + & + & - & ++ & - & + & 24 & + & $+1-$ & - & - \\
\hline 12 & 14 & - & - & + & - & - & ++ & - & - & 14 & - & - & - & - \\
\hline 13 & 20 & - & - & + & - & - & + & - & - & $17 \cdot 5$ & - & + & - & + \\
\hline $14 a$ & 15 & + & $+1-$ & + & - & - & $+1-$ & - & - & $22 \cdot 5$ & - & + & - & + \\
\hline $14 b$ & 17 & + & - & - & - & - & - & - & - & $17 \cdot 5$ & - & + & - & $t$ \\
\hline 15 & 7 & - & - & - & - & - & - & - & - & 14 & - & $+1-$ & - & - \\
\hline 16 & 11 & - & - & - & + & - & + & - & - & $14-17 \cdot 5$ & - & $+1-$ & - & - \\
\hline $17 \mathrm{a}$ & 16 & + & $+1-$ & $+1-$ & $+1-$ & - & + & - & - & 14 & - & + & - & + \\
\hline $17 \mathrm{~b}$ & 19 & + & + & $+1-$ & - & - & - & - & - & 10 & - & + & - & + \\
\hline $18 a$ & 5 & - & - & + & - & - & + & - & - & 19.5 & - & - & - & - \\
\hline $18 \mathrm{~b}$ & 7 & - & - & + & - & - & ++ & - & - & 10 & - & - & - & - \\
\hline $19 a$ & 4 & + & - & + & - & - & $+1-$ & - & - & 12 & - & $+1-$ & - & - \\
\hline $19 b$ & 5 & + & - & + & - & - & $+1-$ & - & - & $11-13$ & - & $+1-$ & - & + \\
\hline $20 a$ & 3 & - & $+1-$ & + & - & - & - & - & - & 3.5 & & & & \\
\hline $20 \mathrm{~b}$ & 8 & - & - & + & - & - & - & - & - & $9-14$ & - & - & $+1-$ & - \\
\hline
\end{tabular}

*Lamellar specimen only.

tation and disorganisation of collagen fibres, and degeneration in keratocytes. ${ }^{14}$

In the four dominant cases DM was predominantly thickened by an irregular increase in thickness of the posterior non-banded portion, while the anterior banded zone was of normal thickness and arrangement (Fig. 15). In these cases an irregular felt-like or bird's nest-like (on SEM) array of matted collagen fibrils was laid down without an orderly pattern, with little basement membrane-like material but with small foci of long-spacing collagen (Fig. 16). This irregular thickening, forming a posterior collagenous layer, was in contrast to the recessive group.

Five recessive cases (six corneas) were examined with TEM; scanning electron microscopy (SEM) was performed in two. Descemet's membrane was evenly thickened. The anterior banded zone was regularly and normally thick. The non-banded zone showed a homogeneous thickening by a more organised deposition of basement membrane-like material, and focal long-spaced collagen, mixed in an orderly matrix with fine fibrillary collagen. No evidence of the bird's-nest disorganised pattern was present as seen in the dominant cases.
Membrane bound melanin granules were seen on both TEM and SEM of dominant cases inside rounded or humped endothelial cells (Figs. 17, 18). Parts of the thickened disorganised Descemet's membrane were bare, without a covering of endothelial cells. In one dominant case there was obvious overgrowth of cells, covering more effete rounded cells with vacuolated cytoplasm. The posterior covering cells were more electron dense, with more organelles present.

Frank multilayering of cells was apparent only in the younger recessive case examined. In the recessive group as a whole there was slightly less tendency for healthier cells to become flattened in an attempt to cover up the effete electron lucent cells. Some areas appeared normal on SEM, but the cratered, vacuolated cells were present in recessive cases. Few of the cells examined in detail showed the marked melanisation seen at light microscopy (Figs. 19A, B).

\section{Discussion}

Although histological studies indicate variations in the pattern of developmental abnormalities of the 


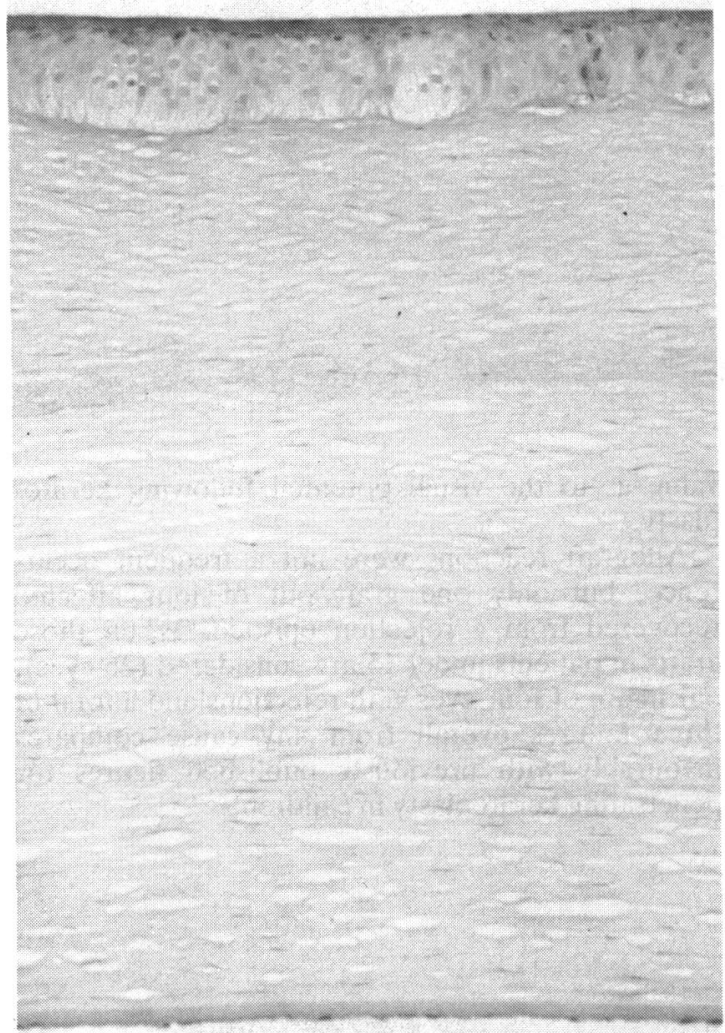

Fig. $12 \mathrm{CHCO}$ (recessive). The basal layers of the epithelium are oedematous, there is loss of Bowman's zone, and Descemet's membrane is slightly thickened $(14 \mu \mathrm{m})$ with a lining of degenerate endothelium periodic acid-Schiff.

corneal endothelium, congenital hereditary corneal oedema of Maumenee (CHCO) appears to be a single, specific clinical entity characterised by the finding at or soon after birth of diffuse corneal oedema affecting both eyes symmetrically without other significant developmental abnormalities of the anterior segment of the eye. The main differential diagnosis is from congenital glaucoma and the mucopolysaccharidoses. CHCO should be readily distinguishable from congenital glaucoma by the finding of a normal corneal diameter, the absence of splits in Descemet's membrane or of any abnormality of the iris, and a normal intraocular pressure. It is noteworthy that in our series of 23 patients five had undergone surgery for glaucoma previously, four having had two or more operations in early infancy for 'congenital glaucoma'. Previous authors have reported similar instances. ${ }^{13} 15$

In the case of mucopolysaccharidosis the corneal

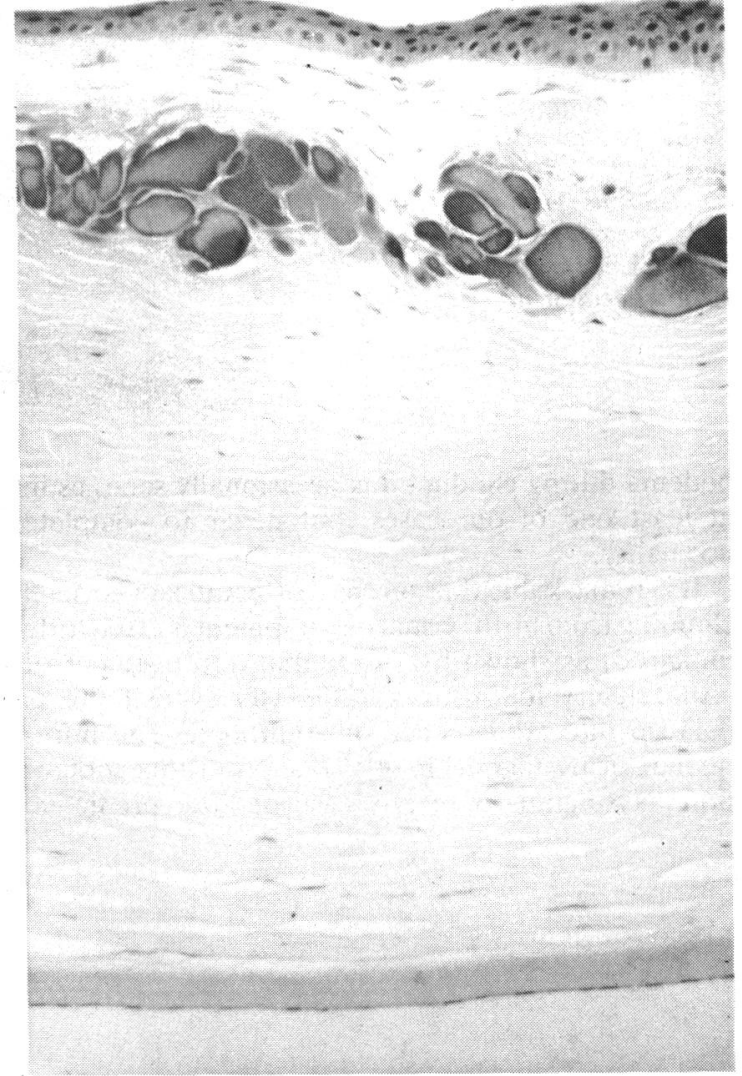

Fig. $13 \mathrm{CHCO}$ (recessive). Moderate atrophy and oedema of the epithelium is seen with partial loss of Bowman's zone and deposition in the superficial stroma of homogeneous protein material characteristic of spheroidal droplet degeneration. Descemet's membrane is considerably thickened $(24 \mu \mathrm{m})$ and has an atrophic endothelial lining. Haematoxylin and eosin.

opacities are in the nature of an infiltration rather than oedema, and usually there are other clinical or biochemical features that may confirm the diagnosis.

Posterior polmorphous dystrophy, if advanced, may appear similar to $\mathrm{CHCO}$ both clinically and histologically, and some authorities have considered that it may represent part of the spectrum of the same developmental anomaly. ${ }^{20}$

With regard to the natural history of $\mathrm{CHCO}$, in seven of our cases there was evidence of progression. Maumenee described a similar progression in two of his original cases and Keates and Cvintal ${ }^{15}$ described a family with a typical recessive pattern who also showed signs of progression. The usual course is, however, for the oedema to remain unchanged for many years. Some temporary regression of the 
Fig. $14 \mathrm{CHCO}$ (dominant). Descemet's membrane is not significantly thickened $(8 \mu \mathrm{m})$ but shows lamination with well defined anterior banded and posterior nonbanded zones and a posterior collagenous layer $(6 \mu \mathrm{m})$ covered by attenuated endothelium. Periodic acid-Schiff.

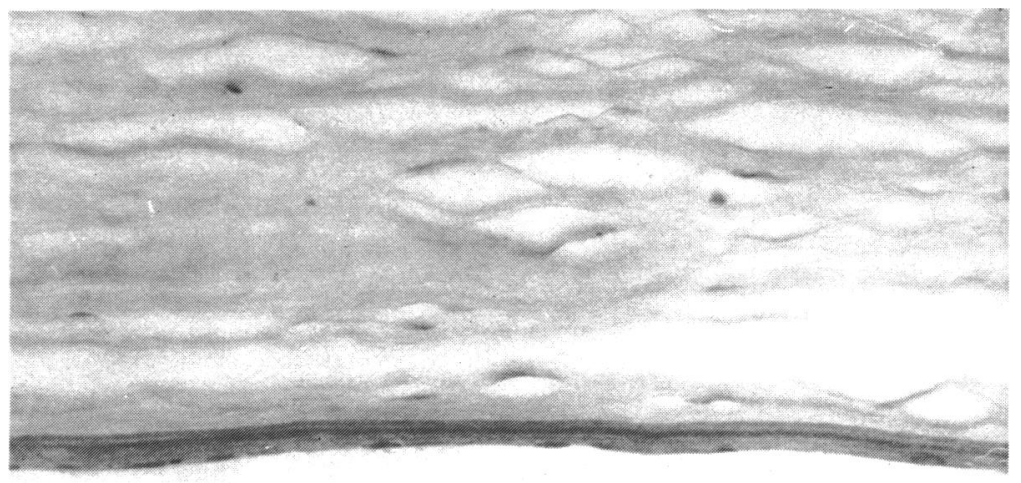

oedema during childhood is occasionally seen, as in at least one of our cases, but never to complete normality.

It is remarkable that, in spite of significant corneal clouding from birth, visual development is often little impaired, as shown by substantial improvement of visual acuity following keratoplasty even if this is delayed into adolescence or adulthood. The infrequency of nystagmus may also support this contention. Nystagmus is in any case of little predictive value as to the visual potential following keratoplasty.

Allograft reactions were not a frequent occurrence, but only one graft out of four affected recovered from a rejection episode. When those grafts in patients under 15 are considered ( 26 eyes), our figure of four eyes with rejections and a total of three failures overall from any cause compares favourably with previously published figures for penetrating keratoplasty in children. ${ }^{21-23}$
Fig. $15 \mathrm{CHCO}$ (dominant). Posterior collagenous layer below endothelial cell and above normal anterior banded zone and thick posterior non-banded zone. $\times 12000 \mathrm{PCL}=$ posterior collagenous layer. $\mathrm{PNBZ}=$ posteriornon-banded zone. $\mathrm{ABZ}=$ anterior banded zone.

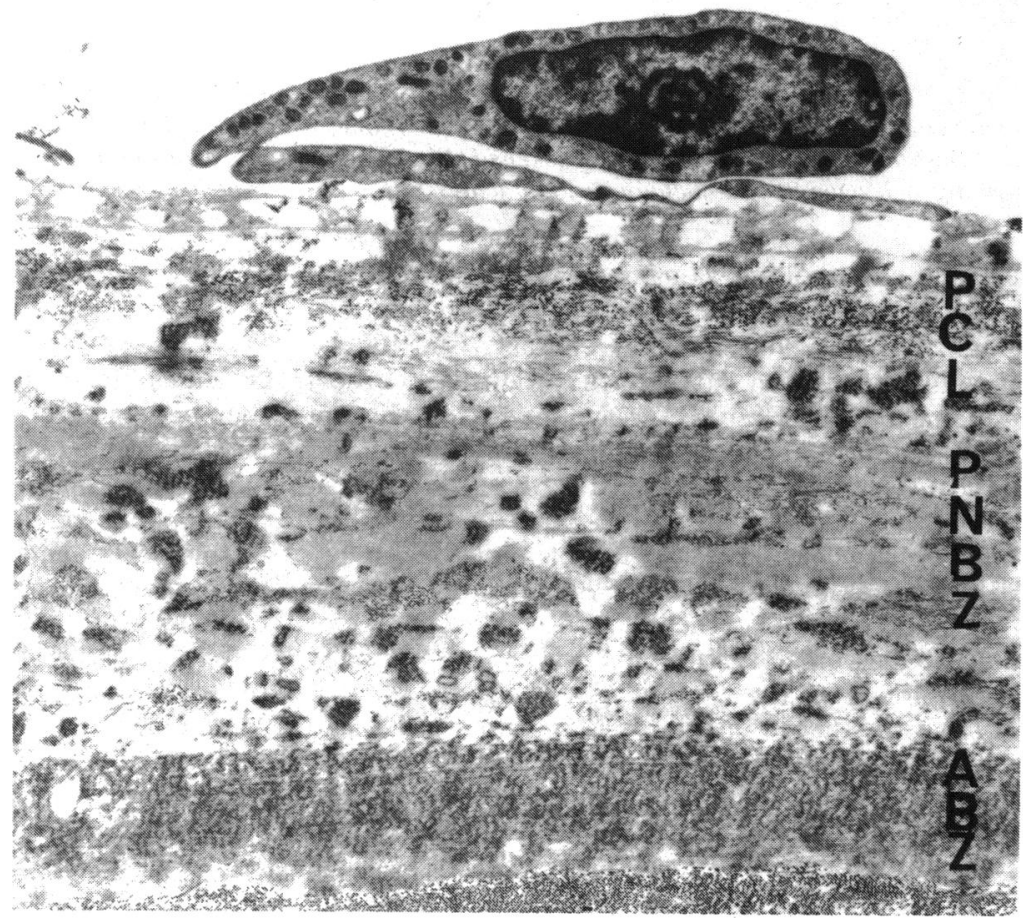


Table 5 Electron microscopic changes

\begin{tabular}{|c|c|c|c|c|c|c|c|c|c|c|c|}
\hline \multirow[t]{3}{*}{ Caseno. } & \multirow[t]{3}{*}{ Age } & \multirow[t]{3}{*}{$S E M$} & \multirow{3}{*}{$\begin{array}{l}\text { Surgery } \\
\text { (previous) }\end{array}$} & \multicolumn{4}{|c|}{ Descemet's membrane } & \multicolumn{4}{|c|}{ Endothelium } \\
\hline & & & & \multirow{2}{*}{$\begin{array}{l}\text { Ant. banded } \\
\text { zone }\end{array}$} & \multicolumn{2}{|c|}{ Postnon-banded zone } & \multirow{2}{*}{$\begin{array}{l}P C L \\
\text { (fibrillary) }\end{array}$} & \multirow[t]{2}{*}{ Absent } & \multirow{2}{*}{\multicolumn{2}{|c|}{$\begin{array}{r}\text { Vacuolated Multi- } \\
\text { layered }\end{array}$}} & \multirow[t]{2}{*}{ Melanin } \\
\hline & & & & & $\begin{array}{l}\text { BM-like } \\
\text { material }\end{array}$ & $\begin{array}{l}\text { longspaced } \\
\text { collagen }\end{array}$ & & & & & \\
\hline \multicolumn{12}{|c|}{ Dominant } \\
\hline & 65 & + & & & & & ++ & + & & . & \\
\hline $5 B$ & 14 & - & & Normal & + & + & + & + & + & + & \\
\hline 7 & 37 & - & & Normal & $-1+$ & ++ & ++ & + & & - & \\
\hline 9 & 63 & - & & Normal & $-1+$ & + & ++ & & & $-1+$ & ++ \\
\hline \multicolumn{12}{|l|}{ Recessive } \\
\hline & 14 & + & & Normal & + & + & - & $+1-$ & ++ & & \\
\hline $14 \mathrm{~A}$ & 15 & + & + & Normal & ++ & ++ & $+1-$ & & & & \\
\hline $18 \mathrm{~B}$ & 7 & + & & Thick & ++ & ++ & - & ++ & + & & \\
\hline 19 & 5 & - & + & Normal & ++ & + & + & & + & & + \\
\hline $20 \mathrm{~A}$ & 3 & - & & Thin-Normal & ++ & + & - & & + & + & \\
\hline $20 \mathrm{~B}$ & 8 & - & & Normal & + & + & - & & + & ++ & \\
\hline
\end{tabular}

Our observations lead us to caution against penetrating keratoplasty in early childhood for CHCO. It seems prudent in most cases to delay surgery until the visual disability can be properly assessed in the knowledge that delay does not appear to prejudice visual results in a successful graft. It is our view that the hazards of corneal graft surgery in infants far outweigh the advantages to be gained from early surgery in this condition. We consider it is reasonable to conclude from our series that penetrating keratoplasty has a relatively good prognosis in $\mathrm{CHCO}$ and is justified in patients whose visual disability warrants it.

Two distinct patterns of inheritance have been described in this condition by Judisch and Maumenee. ${ }^{18}$ They did not examine any patients from a dominant pedigree themselves but quoted the family reported by Pearce et al. ${ }^{14}$ This is the same family (several years earlier) as the one we present. Typically, the recessive type is said to be found earlier and not to be progressive, in contrast to the dominant pattern. We found a few cases which were clearly progressive in both groups. Presentation may be later in the dominant group for reasons other than poor sight-for example, because the families are familiar with the condition and believed until recently that surgery would not be of benefit to them. It is interesting to note that in successive generations of our dominant family presentation has been progressively earlier. Associated symptoms of photophobia are uncommon, but, if the oedema is longstanding, secondary degenerative changes may be

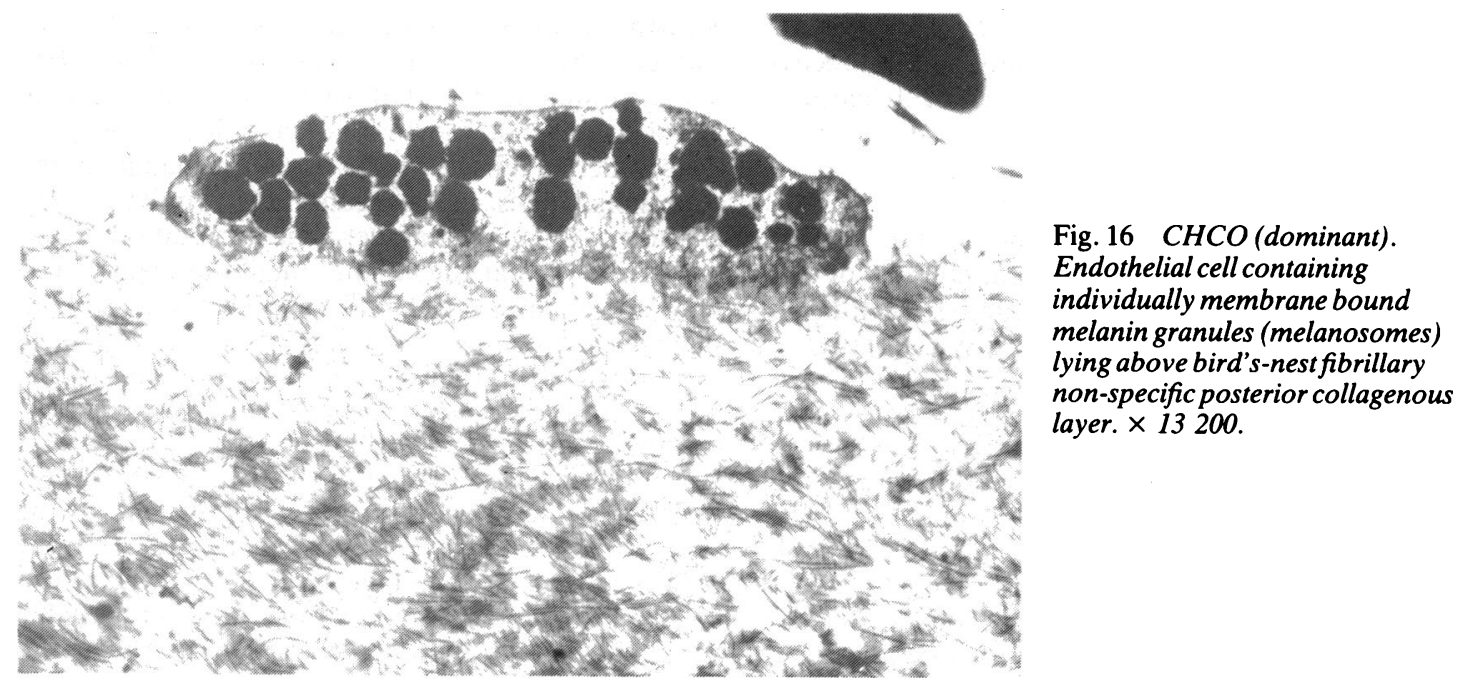

Fig. $16 \mathrm{CHCO}$ (dominant). Endothelial cell containing individually membrane bound granules (melanosomes) lying above bird's-nest fibrillary layer. $\times 13200$ 


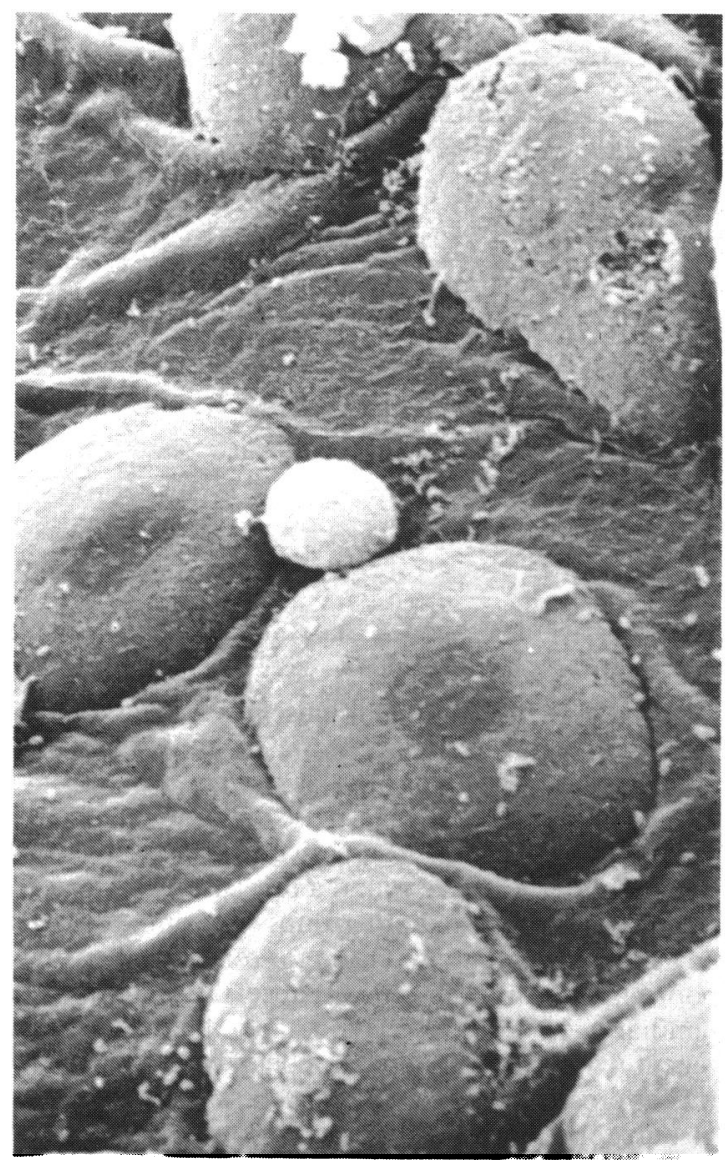

Fig. 17 CHCO (dominant). Humped endothelial cells and bare Descemet's membrane. SEM, × 1133.

seen. Nystagmus may be found but infrequently in both groups. We do not believe it is possible to differentiate between the dominantly and the recessively inherited patterns from the clinical features alone.

\section{HISTOLOGY}

Following Maumenee's description ${ }^{8}$ of the clinical features and some of the histological features of this complex endothelial dystrophy, a number of authors, whose reports were summarised by Waring et al. ${ }^{24}$ illustrated different facets of the disease. Most authors agree that the epithelial and basement membrane changes, which are probably secondary in nature, consist of variability of thickness, from three to seven layers of cells, with focal loss of polarity and intracellular oedema, especially at the base of the epithelium. Frank ulceration is unusual. While Bowman's layer has been reported as being intact, we found most of our cases showed some disruption.
The clinically observed stromal oedema is much harder to assess histologically. Although slit-lamp examination and measurement of the thickness of stroma may be difficult or even impossible without ultrasonic pachymetry, histological measurements are probably even more inaccurate, since artefact is difficult to control. In this review we decided therefore not to measure stromal thickness or to comment on the diameter of stromal collagen fibrils, or to attempt to assess the amount of fluid separating the fibrils or lamellae. We did note in two of our longstanding but genetically indisputable cases of autosomal dominant disease neovascularisation of the corneal stroma. Previously this has not been reported, but this may be because the dominant condition is much less common and fewer cases have been examined. These two cases also showed spheroidal degeneration, which is almost certainly a reflection of the longstanding nature of the disease. It is interesting that our oldest recessive patient also showed this, although, arguably, there may have been a climatic (actinic) contribution as well, which could have accelerated the process.

We were fortunate in having Descemet's membrane and endothelium to examine in most cases. Some earlier work was impaired by artefactual loss of these structures and consequent inability to recognise the underlying pathogenesis of stromal oedema. It is well known that shearing forces during surgery and histological preparation can cause artefactual loss of cells which may not reflect the appearance in vivo. We observed, on SEM, vacuolation and ulceration of endothelial cells. Such degeneration is, however, a focal process, endothelial cells in some areas being present in normal numbers and of a size relative to the age of the patient. ${ }^{25}$

The variability in the nature of the endothelial cells is further evidenced in one case examined by SEM, wherein the endothelium was (within one SEM biopsy) thinned, ulcerated, vacuolated, heaped up in double layers, and even normal, and this may explain the conflicting reports on the nature of changes in the endothelial cells in this condition. Similarly, the amount of thickening of Descemet's membrane, and the nature of that thickening, might be expected to vary above the endothelial cells according to the stage in the dystrophy at which the cells degenerate. This may explain the wide range of reported abnormalities in the literature, which vary from absence ${ }^{14}$ (probably artefactual), thinned, ${ }^{1013.161726}$ to thickened $^{12} 1417$ with multilamination of the endothelium. ${ }^{11}$

If Descemet's membrane and any underlying acquired posterior collagenous layer ${ }^{27}(\mathrm{PCL})$ can be regarded as an 'archaeological record" ${ }^{19}$ of the insults suffered by the membrane as a result of endothelial cell dysfunction, then the variation in the mem- 


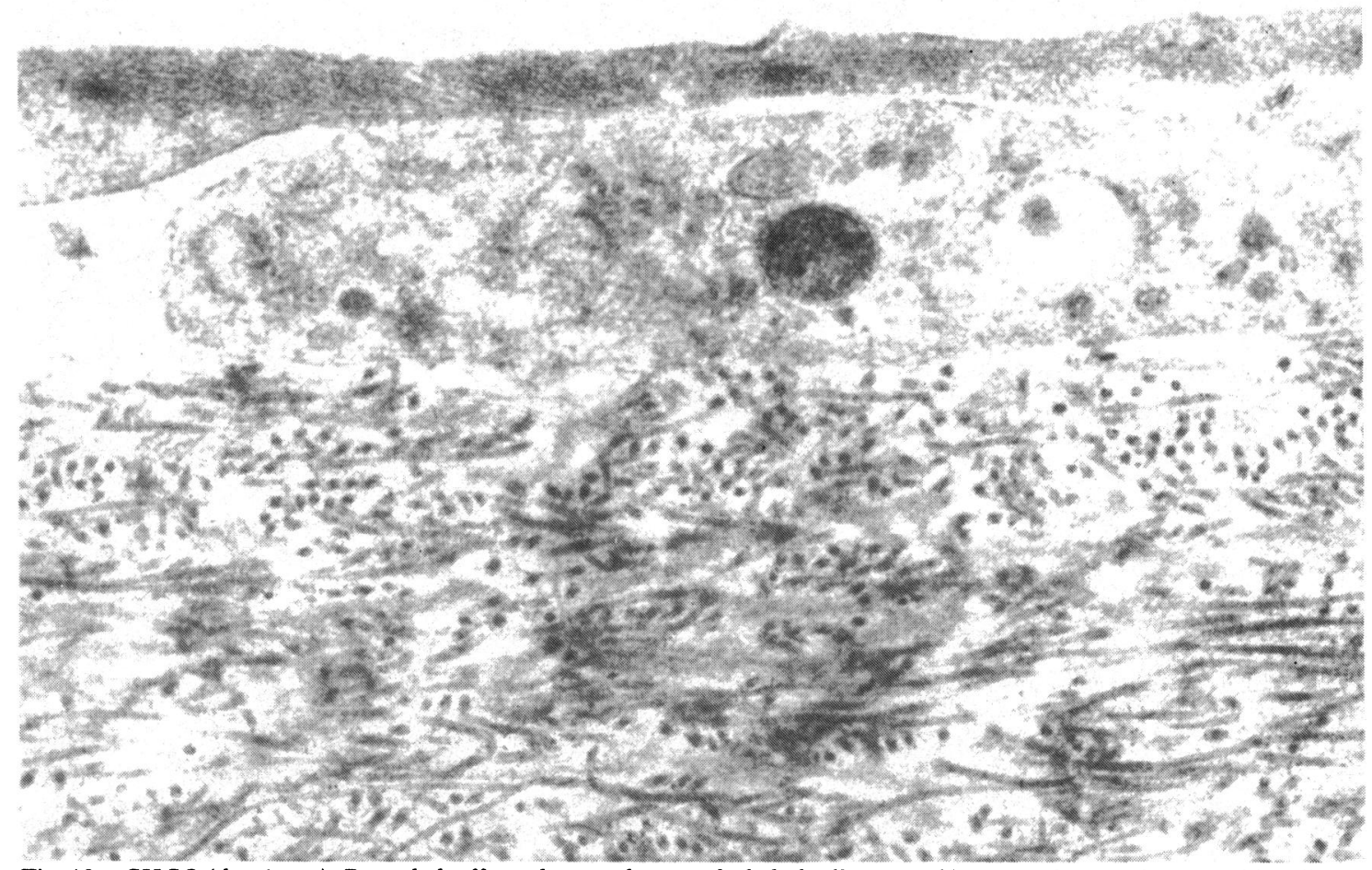

Fig. 18 CHCO (dominant). Rounded, effete, electron dense endothelial cells covered by more electron dense, viable cells. Note bird's-nest fibrillary collagen pattern in posterior collagenous layer. $\times 40000$.

brane's structure should reflect the variation in physiological circumstances and function of the endothelial cell beneath. We did observe that nonspecific bird's-nest pattern of fibrillary collagen deposited as a $\mathrm{PCL}^{27}$ was more common in the autosomal dominant group. This type of PCL has been described following a wide variety of traumatic conditions as well as in CHCO. In at least some of our cases it could not be attributed to previous surgery. We did not observe the fibrocellular type of PCL, ${ }^{27}$ though this may be a possible variant, especially in those cases where fibroblastic metaplasia of endothelial cells has been observed. ${ }^{10}{ }^{16}$ It is interesting that in the dominant group the anterior banded zone of Descemet's membrane was present and of normal thickness. This supports the contention that, in utero, the function of endothelial cells between the third and eighth month of gestation was normal, permitting normal secretion of collagen and banding of this zone. This phase of anterior zone (ABZ) growth in normal corneas appears to occur at a faster rate than the secretion of the posterior non-banded zone, as the whole of the three $\mu \mathrm{m}$ thickness of the $\mathrm{ABZ}$ is laid down in four months while the subsequent deposition of the posterior non-banded zone takes longer, with accumulation of the mixed base- ment membrane and collagen material occurring at a slower rate, with a more gradual slope on the growth curve. ${ }^{28}{ }^{29}$ In both our autosomal dominant and recessive groups the thickness of the whole Descemet's membrane is greatly increased, and the distribution of the results of the thickness compared with the predicted thickness (Fig. 20) seems to point to growth at the accelerated prenatal phase rate continuing after birth, without the usual slowing down, especially in the recessive group. This makes the observation from our cases of recessive disease-that Descemet's membrane is usually thickened not by a non-specific fibrillary PCL but by accumulation of normal, posterior, non-banded zone material (mixed collagen and basement membrane)-even more fascinating. It implies that the normal restrictive pattern of endothelial synthesis and secretion is not enforced.

There does appear to be a subtle difference between dominant and recessive cases, both quantitatively in the thickness of collagen laid down in the expansion of Descemet's membrane and in the apparent rate of such deposition. Qualitative differences are also seen in the increased tendency of the deranged endothelium to lay down a normally constituted, homogeneous, posterior, non-banded 


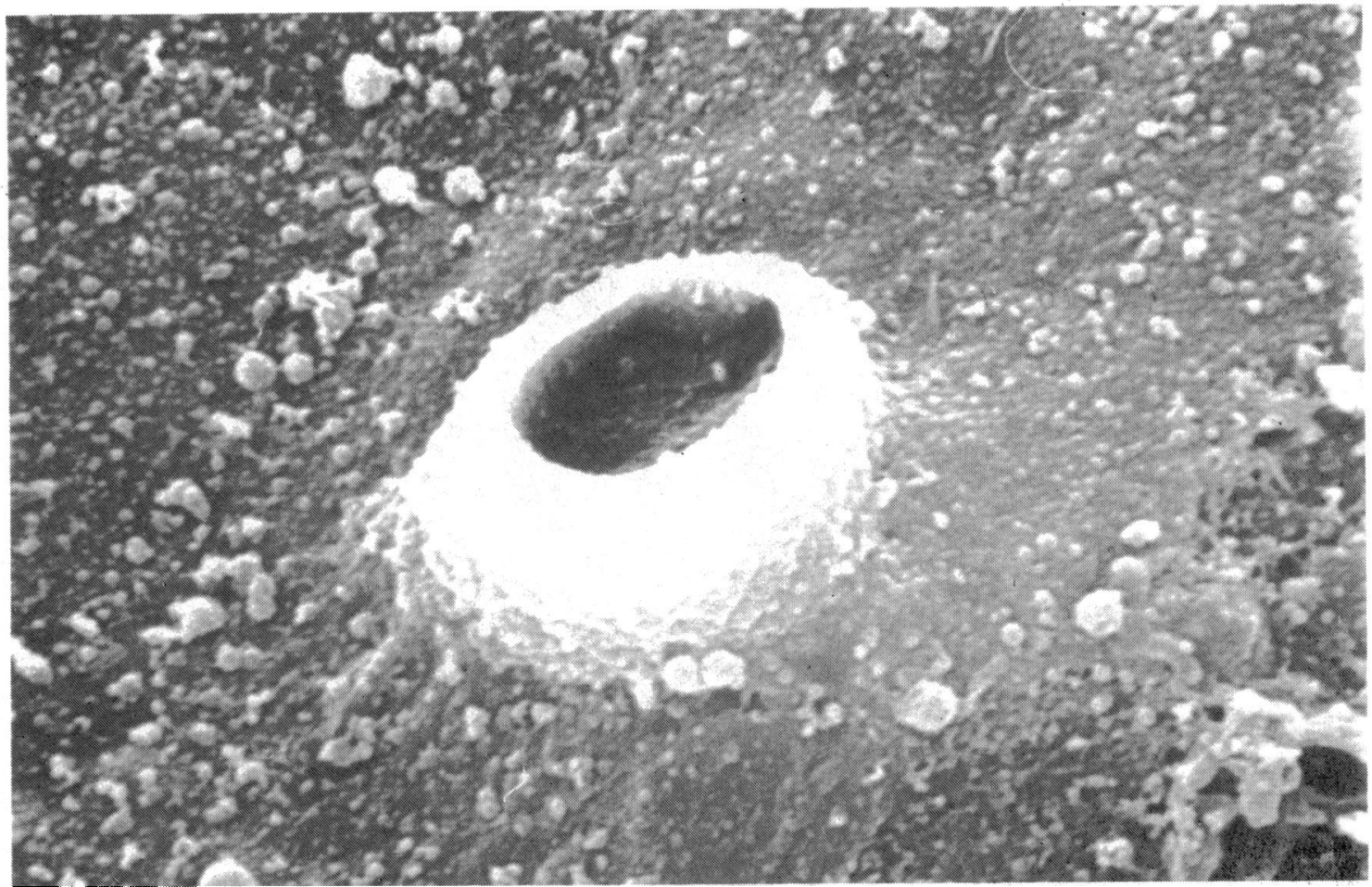

Fig. $19 C H C O$ (recessive). A: Endothelial cell. Note microvilli projecting into the lumen of the crater. SEM, $\times 20000$.

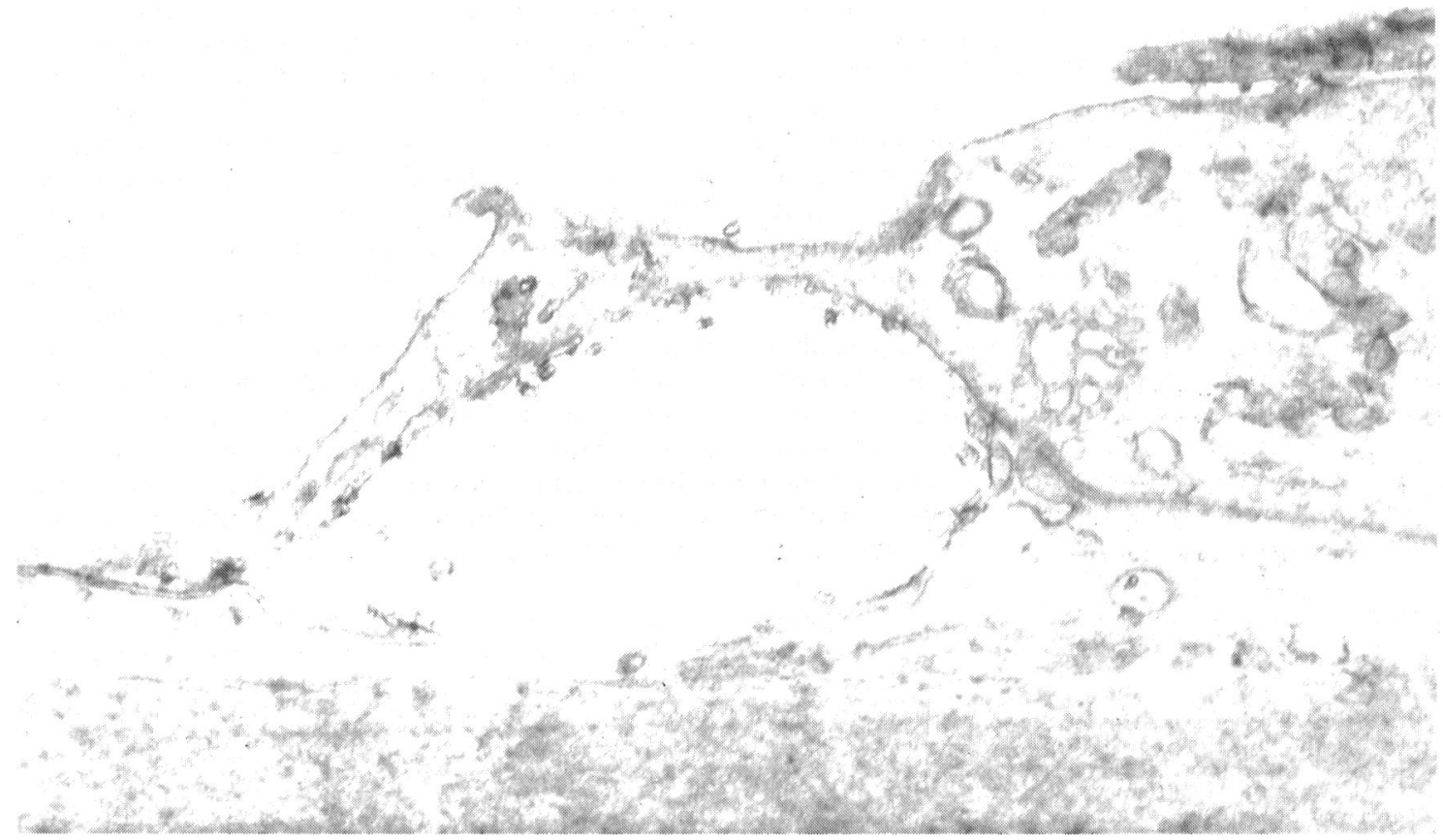

B: Endothelial cell with vacuole with microvilli projecting into it. $\times 26000$. 


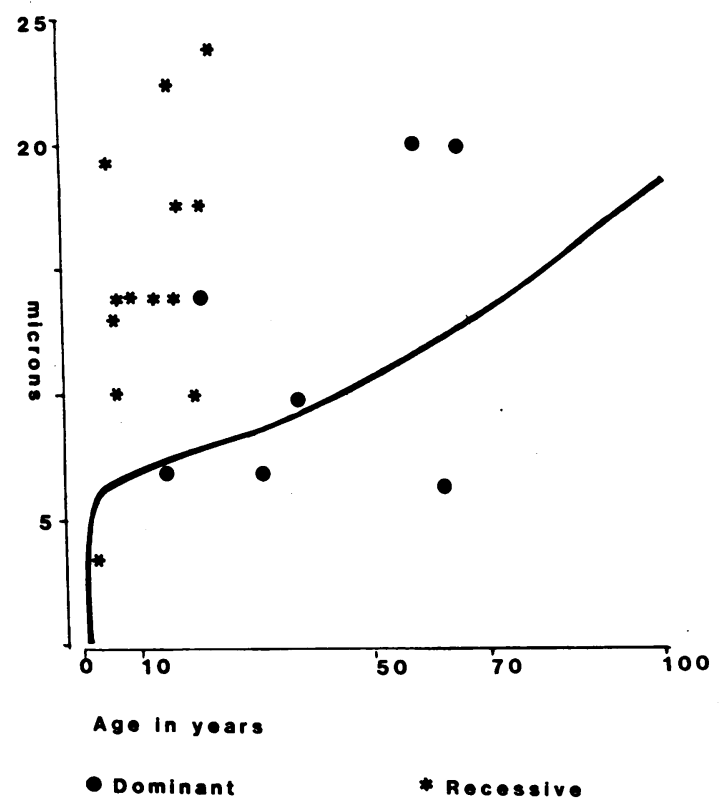

Fig. 20 Measurement of the thickness of Descemet's membrane compared to curve of predicted values for age.

Descemet's membrane in the recessive cases, with an accelerated rate of deposition, rather than a reactive fibrillary posterior collagenous membrane.

The changes in Descemet's membrane ideally should mirror those seen in the endothelium. If the underlying endothelial cells are absent or attenuated, then it is inevitable that the formation of Descemet's membrane will be arrested at the stage when the cell is lost. Non-specific reactive fibrillary change might also be expected if there has been fibroblastic metaplasia. ${ }^{101623}$ We could not demonstrate endothelial cell intracytoplasmic filaments in our cases. We did see multilayering of cells, but not the marked low cuboidal embryonic type of cells described as being 'intermediate ${ }^{23}$ in a case with some features (at histological level) of posterior polymorphous dystrophy (PPD). PPD, it has been claimed, is a related condition to $\mathrm{CHCO}$, and one case of ours, a recessive, showed epithelium-like cells with marked multilayering accompanied by a thin Descemet's membrane at age 3, but a thicker than usual Descemet's at the time of keratoplasty on the second eye at the age of 8 years. These epithelium-like cells are usually associated with PPD, but this case was clinically indistinguishable from other cases of CHCO according to our criteria.

The corneal endothelium develops from the neural crest $^{30}$ and, as such, the cells are thought to be pluripotential. This has been used as a basis for recent reclassification ${ }^{31}$ of the diseases affecting endothelium and also as an explanation of the metamorphosis of endothelial cells into fibroblastic and epithelium-type cells. The incidence of melanin in 'endothelial cells' in our series was quite high, and others have reported their presence in CHCO. The presence of melanin within endothelial cells has been thought to be due either to phagocytosis of melanin liberated from anterior border cells or to migration of such cells to cover bare Descemet's membrane and maintain its structural integrity. ${ }^{32} 33$ The electron microscopy of the melanin granules shows them to be melanosomes, of the smaller size associated with other neural crest derived melanocytes, rather than engulfed particles within phagolysosomes. Although these cells could have migrated from the anterior border, it is tempting to describe these melanocytelike cells as another example of the metaplastic range of the endothelial cell.

Degeneration in the form of vacuolation was first described by Pouliquen et al. ${ }^{34}$ and we demonstrated these cistern-like vacuoles clearly, both in SEM and TEM. The overriding of cells, which appear to be an effort to cover ineffectual (presumably leaky) endothelial cells, have not been described before in CHCO.

Our findings support the hypothesis that in cases with thinned or attenuated Descemet's membrane, complete endothelial dysfunction occurs in utero, so that only fetal $\mathrm{ABZ}$ is secreted. Thick Descemet's membrane on the other hand is the probable result of persistent dystrophic endothelium secreting a posterior collagenous layer. ${ }^{19}$ In addition, however, we would like to postulate that the process, in the recessive group especially, also constitutes a persistent failure of growth regulation, leading to accumulation of a functionally abnormal and structurally exaggerated form of posterior nonbanded Descemet's membrane.

\section{References}

1 Komoto J. Congenital hereditary opacities of the cornea. Klin Monatsbl Augenheilkd 1909; 47: 445.

2 Armaignac M. Opacitie congénitale à peu pres complête des deux cornées chez deux enfants d'une même famille. Bull Mem Soc Fr Ophtalmol 1911; 28: 164-73.

3 Fischer FP, Ancona S. Über angeborne familiare Hornhauttrübung. Acta Ophthalmol (Kbh) 1936; 31: 406-13.

4 Turpin $R$, Tisserand $M$, Serane J. Opacities cornéennes heréditaires et congènitales; et reparties sur troise gènèrations et atteignent deux jumelles monozygotes. Arch Ophthalmol 1939; 3: 109-11.

5 Contino F. Intorbidamento congenito familiare della cornea. Ann Ottalmol Clin Oculist 1941; 69: 438-439.

6 Blum JD. Relations between hereditofamilial degenerations and the congenital opacities of the cornea. Ophthalmologica 1945; 109: 123-36.

7 Fransechetti A, Babel J. A study of the anatomical classification of familial degenerations of the cornea. Ophthalmologica 1949; 109: 169-72. 
8 Maumenee AE. Congenital hereditary corneal dystrophy. Am J Ophthalmol 1960; 60: 1114-24.

9 Antine B. Histology of congenital hereditary corneal dystrophy. Am J Ophthalmol 1970; 69: 964-9.

10 Kanai A, Kaufman HE. Further electron microscopic study of hereditary corneal edema. Invest Ophthalmol Vis Sci 1971; 10: 545-54.

11 Kenyon KR, Antine B. The pathogenesis of congenital hereditary endothelial dystrophy of the cornea. Am J Ophthalmol 1971; 72: 787-95.

12 Limaye SR, Kothare SN. Congenital hereditary corneal dystrophy - a histological report. Eye, Ear, Nose and Throat Monthly 1972; 51: 58-62.

13 Rodrigues MM, Waring GO, Laibson PR, Weinret S. Endothelial alterations in congenital corneal dystrophies. Am J Ophthalmol 1975; 80: 678-89.

14 Pearce WG, Tripathi RC, Morgan G. Congenital endothelial corneal dystrophy. Clinical, pathological and genetic study. $\mathrm{Br} J$ Ophthalmol 1969; 53: 577-91.

15 Keates RK, Cvintal Y. Congenital hereditary corneal dystrophy. Am J Ophthamol 1960; 60: 892-4.

16 Kanai A, Waltman S, Pol'ck F, Kaufman HE. Electron microscopic study of hereditary corneal edema. Invest Ophthalmol Vis Sci 1971; 10: 89-99.

17 Kenyon KR, Maumenee AE. Further studies of congenital hereditary endothelial dystrophy of the cornea. Am J Ophthalmol 1973; 76: 419-39.

18 Judisch GF, Maumenee IH. Clinical differentiation of recessive congenital hereditary endothelial dystrophy and dominant hereditary endothelial dystrophy. Am J Ophthalmol 1978; 85: 606-12.

19 Waring GO, Bourne WM, Edelhauser HF, Kenyon K. The corneal endothelium. Normal and pathologic structure and function. Ophthalmology 1982; 89: 531-90.

20 Chan CC, Green WR, Barraquer J, Barraquer-Somers E, de la Cruz Z. Similarities between posterior polymorphous and hereditary dystrophies. Cornea 1982; 1: 155-72.

21 Waring GO, Laibson PR. Keratoplasty in infants and children. Ophthalmology 1977; 83: 283-96.

22 Brown SI, Salamon SM. Wound healing in congenitally opaque infant corneas. Am J Ophthalmol 1983; 95: 641-4.
23 Volker-Dieben HJM, Kok-van Alphen CC, D'Amaro J. Keratoplasty in children. In: Volker-Dieben HJM, ed. The effect of immunological and nonimmunological factors on corneal survival. The Hague: Junk, 1984: chapter 8.

24 Waring GO, Rodrigues MM, Laibson PR. Corneal dystrophies. II. Endothelial dystrophies. Surv Ophthalmol 1978; 23: 147-68.

25 Murphy C, Alvardo J, Juster R, et al. Prenatal and postnatal cellularity of the human corneal endothelium. Invest Ophthalmol Vis Sci 1984; 25: 312-22.

26 Kenyon KR, Maumenee AE. The histological and ultrastructural pathology of congenital hereditary endothelial dystrophy. A case report. Invest Ophthalmol Vis Sci 1968; 7: 475-500.

27 Waring GO. Posterior collagenous layer of the cornea. Ultrastructural classification of abnormal collagenous tissue posterior to Descemet's membrane in 30 cases. Arch Ophthalmol 1982; 100: 122-34.

28 Murphy C, Alvardo J, Juster R. Prenatal and postnatal growth of the human Descemet's membrane. Invest Ophthalmol Vis Sci 1984; 25: 1402-15.

29 Johnson DH, Bourne WM, Campbell J. The ultrastructure of Descemet's membrane. 1-Changes with age. Arch Ophthalmol 1982; 100: 1942-7.

30 Johnston MC, Noden DM, Hazelton RD, Coulombre JL, Coulombre AJ. Origins of avian ocular and periocular tissues. Exp Eye Res 1979; 29: 27-43.

31 Bahn CF, Falls HF, Varley GA, Meyer Edelhauser HF, Bourne WM. Classification of corneal endothelial diseases based on neural crest origin. Ophthalmology (Rochester) 1984; 91: 558-63.

32 Wolter JR. Replacement of corneal endothelium by melanocytes. Graefes Arch Clin Exp Ophthalmol 1981; 217: 247-53.

33 Snip RC, Green WR, Kreutzer EW, Hirst LW, Kenyon KR. Posterior corneal pigmentation and fibrous proliferation by iris melanocytes. Arch Ophthalmol 1981; 99: 1232-8.

34 Pouliquen Y, Graf B, Hamada R, et al.Dystrophie congénitale de la cornée. Etude en microscopie optique et en microscopie electronique. Arch Ophtalmol (Paris) 1972; 32: 391-414. 